\title{
TINGKAT PENGETAHUAN MAHASISWA PROFESI PROGRAM STUDI PENDIDIKAN DOKTER GIGI TERHADAP PENGGUNAAN ANTIBIOTIK DI RSGMP UNSRAT MANADO
}

\author{
${ }^{1}$ Juwita Purnamasari \\ ${ }^{2}$ Pemsy M. Wowor \\ ${ }^{3}$ Elita Tambunan \\ ${ }^{1}$ Kandidat Skripsi Program Studi Pendidikan Dokter Gigi Fakultas Kedokteran \\ ${ }^{2}$ Bagian Farmakologi Fakultas Kedokteran \\ ${ }^{3}$ Program Studi Pendidikan Dokter Gigi \\ Universitas Sam Ratulangi Manado \\ E-mail: purnamasarijuwita04@gmail.com
}

\begin{abstract}
Antibiotics are substances produced by microbes, especially fungi that can inhibit or eradicate other microbial species. The use of antibiotics in Indonesia is very alarming. According to WHO, Indonesia was ranked 8th out of 27 countries that were resistant to antibiotics. The health workers' knowledge, especially of dentists and professional students is needed to prevent the irrational use of antibiotics. This was a descriptive study with a cross sectional approach. Samples were as many as 71 Dentistry Study Program students in RSGMP Unsrat. The instrument used in the study was a questionnaire about knowledge of antibiotic usage. The results showed that $64.79 \%$ of students had poor knowledge level of antibiotic usage. Conclusion: In this study, most students of Dentistry Study Program in RSGMP Unsrat Manado belonged to the poor category in knowledge of antibiotic usage.
\end{abstract}

Keywords: knowledge, use of antibiotics

\begin{abstract}
Abstrak: Antibiotik adalah zat yang dihasilkan oleh suatu mikroba terutama fungi yang dapat menghambat atau membasmi mikroba jenis lain. Penggunaan antibiotik di Indonesia sangat memprihatinkan. Data WHO menyebutkan bahwa Indonesia menduduki peringkat ke-8 dari 27 negara resisten terhadap antibiotik. Tingkat pengetahuan para tenaga kesehatan khususnya dokter gigi dan mahasiswa profesi sangat dibutuhkan untuk mencegah pemakaian antibiotik yang tidak rasional yang dapat menimbulkan banyak sekali kerugian. Penelitian ini menggunakan metode deskriptif dengan pendekatan potong lintang. Sampel yang digunakan sebanyak 71 mahasiswa profesi Program Studi Pendidikan Dokter Gigi. Instrumen penelitian ialah kuesioner tentang pengetahuan antibiotik. Hasil penelitian menunjukkan bahwa tingkat pengetahuan dari 64,79\% mahasiswa profesi terhadap penggunaan antibiotik di RSGMP Unsrat Manado termasuk dalam kategori kurang baik. Simpulan: Sebagian besar mahasiswa profesi Program Studi Pendidikan Dokter Gigi di RSGMP Unsrat Manado memiliki tingkat pengetahuan mengenai penggunaan antibiotik termasuk dalam kategori kurang baik
\end{abstract}

Kata kunci: pengetahuan, penggunaan antibiotik

Antibiotik adalah zat yang dihasilkan oleh suatu mikroba terutama fungi yang dapat menghambat atau membasmi mikroba jenis lain. Hampir sebagian besar masyarakat Indonesia sudah sering mendengar bahkan menggunakan antibiotik. Antibiotik memiliki manfaat yang tidak diragukan lagi jika digunakan sesuai dengan aturan yang tepat, namun jika tidak digunakan secara tepat maka dapat menimbulkan banyak 
sekali kerugian. Penggunaan antibiotik di Indonesia sangat memrihatinkan. Data WHO tahun 2009 menyebutkan bahwa Indonesia menduduki peringkat ke-8 dari 27 negara resistensi terhadap antibiotik. Hal ini disebabkan karena penggunaan antibiotik yang tidak rasional. ${ }^{1-3}$

Penelitian yang dilakukan di RSUD Dr. Soetomo dan RSUD Dr. Kariadi tahun 2008 menunjukkan bahwa 84\% pasien di rumah sakit mendapatkan resep antibiotik, $53 \%$ sebagai terapi, $15 \%$ sebagai profilaksis, dan 32\% untuk indikasi yang tidak di ketahui. Faktor-faktor pendukung penggunaan antibiotik secara tidak rasional meliputi kurangnya pengetahuan dari tenaga kesehatan dalam ilmu obat-obatan, adanya kebiasaan meresepkan jenis atau merek obat tertentu, kepercayaan masyarakat terhadap jenis atau merek obat tertentu dan informasi yang tidak tepat. Pengetahuan dari tenaga kesehatan menjadi salah satu faktor yang dapat memengaruhi penggunaan antibiotik secara tidak rasional karena jika tenaga kesehatan tidak mempunyai pengetahuan tentang antibiotik maka akan terjadi kesalahan dalam hal peresepan. $^{4,5}$

Dalam kedokteran gigi antibiotik sangat berperan penting khususnya dibidang bedah mulut. Antibiotik digunakan sebagai profilaksis antibiotik dan sebagai pengobatan kasus-kasus peradangan, oleh karena itu tingkat pengetahuan para tenaga kesehatan khususnya dokter gigi dan mahasiswa profesi yang nantinya akan menjadi dokter gigi sangat dibutuhkan untuk mencegah pemakaian antibiotik yang tidak rasional yang akan menimbulkan banyak kerugian. Penelitian tentang tingkat pengetahuan penggunaan antibiotik pernah dilakukan oleh Syukrinawati RP, 2014 pada mahasiswa kepaniteraan klinik Departemen Bedah Mulut RSGM-P FKG USU, diperoleh data responden secara umum memiliki persentase yaitu persentase terbesar kategori cukup 56\%, kategori kurang 32\% dan kategori baik 12\%.,

Penulis tertarik untuk meneliti mengenai tingkat pengetahuan mahasiswa profesi program studi pendidikan dokter gigi terhadap penggunaan antibiotik di RSGM UNSRAT Manado karena salah satu penyebab penggunaan antibiotik yang tidak rasional ialah karena kurangnya faktor pengetahuan. Alasan memilih sampel tersebut ialah karena mahasiswa profesi saat ini bisa dikatakan hampir setiap hari berhubungan dengan peresepan antibiotik dan nantinya mahasiswa profesi ini akan menjadi dokter gigi yang tidak terlepas dari peresepan antibiotik di tempat praktek.

\section{BAHAN DAN METODE PENELITIAN}

Penelitian ini merupakan penelitian deskriptif dengan pendekatan potong lintang. Jumlah sampel yang digunakan sebanyak 71 responden pada mahasiswa profesi program studi pendidikan dokter gigi yang sedang dan telah melewati Departemen Bedah Mulut, teknik pengambilan sampel yang digunakan ialah purposive sampling. Data penelitian yang digunakan berupa data primer yang diperoleh dengan cara menyebarkan kuesioner kepada mahasiswa profesi yang menjadi sampel penelitian. Dalam pengambilan data responden tidak dikumpulkan dalam satu ruangan tertentu tetapi tim peneliti yang secara langsung mendatangi responden yang telah bersedia ikutserta dalam penelitian ini dan membagikan kuesioner kemudian secara langsung responden menjawab pertanyaanpertanyaan dalam kuesioner yang telah disiapkan.

Data diolah secara manual dan disajikan berdasarkan distribusi frekuensi dalam bentuk tabel kemudian dianalisis secara deskriptif berdasarkan hasil persentase.

\section{HASIL PENELITIAN}

Tabel 1. Karakteristik responden mahasiswa profesi program studi pendidikan dokter gigi

\begin{tabular}{ccc}
\hline Jenis kelamin & $\mathrm{n}$ & $\%$ \\
\hline Laki-laki & 4 & 33,8 \\
Perempuan & 47 & 66,2 \\
Total & 71 & 100 \\
\hline
\end{tabular}


Hasil penelitian tentang tingkat pengetahuan mahasiswa profesi program studi pendidikan dokter gigi terhadap penggunaan antibiotik di RSGM UNSRAT Manado berdasarkan hasil analisis jawaban kuesioner secara umum kategori baik (nilai 76-100\%) sebanyak 2,82\%, kategori cukup baik (nilai 56-75\%) sebanyak 32,39\% dan kategori kurang baik (nilai $<56 \%$ ) sebanyak $64,79 \%$.

Tabel 3. Distribusi frekuensi pengetahuan responden tentang penggunaan antibiotik secara umum

\begin{tabular}{ccc}
\hline Kategori & $\mathrm{n}$ & $\%$ \\
\hline Baik & 2 & 2,82 \\
Cukup baik & 23 & 32,39 \\
kurang baik & 46 & 64,79 \\
Total & 71 & 100 \\
\hline
\end{tabular}

Hasil penelitian tingkat pengetahuan mahasiswa profesi program studi pendidikan dokter gigi terhadap penggunaan antibiotik di RSGM UNSRAT Manado dalam hal defenisi dan klasifikasi antibiotik ialah sebagai berikut kategori baik (nilai 76-100\%) yaitu 8,45\%, kategori cukup baik (nilai 56-75\%) yaitu 28,17\%, kategori kurang baik (nilai $<56 \%$ ) yaitu $63,38 \%$.

Tabel 4. Distribusi frekuensi tingkat pengetahuan responden tentang definisi dan klasifikasi antibiotik

\begin{tabular}{ccc}
\hline Kategori & $\mathrm{n}$ & $\%$ \\
& & \\
\hline Baik & 6 & 8,45 \\
Cukup baik & 20 & 28,17 \\
Kurang baik & 45 & 63,38 \\
Total & 71 & 100 \\
\hline
\end{tabular}

Dalam hal dosis antibiotik diperoleh hasil sebagai berikut untuk kategori tingkat pengetahuan baik (nilai 76-100\%) yaitu sebanyak 1,41\%, kategori cukup baik (nilai 56-75\%) sebanyak 19,72\% dan kategori kurang (nilai $<56 \%$ ) baik sebanyak $78,87 \%$.
Tabel 2. Distribusi frekuensi tingkat pengetahuan responden tentang dosis antibiotik

\begin{tabular}{ccc}
\hline Kategori & $\mathrm{n}$ & $\%$ \\
\hline Baik & 1 & 1,41 \\
Cukup baik & 14 & 19,72 \\
Kurang baik & 56 & 78,87 \\
Total & 71 & 100 \\
\hline
\end{tabular}

Dari hasil penelitian tentang pengetahuan responden dalam hal indikasi penggunaan antibiotik ialah kategori baik (nilai 76-100\%) sebanyak 7,04\%, kategori cukup baik (nilai 56-75\%) sebanyak $36,62 \%$ dan kategori kurang baik (nilai $<56 \%$ ) sebanyak 56,34\%.

Tabel 5. Distribusi frekuensi tingkat pengetahuan responden tentang indikasi penggunaan antibiotik.

\begin{tabular}{ccc}
\hline Kategori & $\mathrm{n}$ & $\%$ \\
\hline Baik & 5 & 7,04 \\
Cukup baik & 26 & 36,62 \\
Kurang baik & 40 & 56,34 \\
Total & 71 & 100 \\
\hline
\end{tabular}

Hasil penelitian tentang pengetahuan antibiotik dalam hal efek samping diperoleh persentase tertinggi yaitu kategori kurang baik (nilai $<56 \%$ ) sebanyak 46,48\%, kategori cukup baik (nilai 5675\%) sebanyak 43,66\% kemudian kategori baik (nilai 76-100\%) hanya 9,86\%

Tabel 6. Distribusi frekuensi tingkat pengetahuan responden tentang efek samping penggunaan antibiotik

\begin{tabular}{ccc}
\hline Kategori & $\mathrm{n}$ & $\%$ \\
\hline Baik & 7 & 9,86 \\
Cukup baik & 31 & 43,66 \\
Kurang baik & 33 & 46,48 \\
Total & 71 & 100 \\
\hline
\end{tabular}

Hasil penelitian tentang pengetahuan antibiotik dalam hal resistensi terhadap antibiotik diperoleh persentase tertinggi yaitu kategori cukup baik (nilai 56-75\%) dengan persentase 49,30\%, sedangkan kategori baik (nilai 76-100\%) hanya 19,72\% dan kategori kurang baik (nilai 
$<56 \%)$ sebanyak 30,98\%.

Tabel 7. Distribusi frekuensi tingkat pengetahuan responden tentang resistensi antibiotik

\begin{tabular}{ccc}
\hline Kategori & $\mathrm{n}$ & $\%$ \\
\hline Baik & 14 & 19,72 \\
Cukup baik & 35 & 49,30 \\
Kurang baik & 22 & 30,98 \\
Total & 71 & 100 \\
\hline
\end{tabular}

\section{BAHASAN}

Pengetahuan seseorang merupakan hal yang memengaruhi tindakan seseorang. Pengetahuan dapat menjadi salah satu faktor yang dapat memengaruhi penggunaan antibiotik secara tidak rasional, karena pengetahuan merupakan faktor utama dalam pembuatan resep. ${ }^{8}$

Berdasarkan hasil penelitian tingkat pengetahuan mahasiswa profesi program studi pendidikan dokter gigi terhadap penggunaan antibiotik di RSGM UNSRAT Manado didapatkan hasil dengan kategori baik sebanyak 2,82\% , kategori cukup baik sebanyak 32,39\% dan kategori kurang baik 64,79\%. Meskipun ada beberapa responden yang memiliki tingkat pengetahuan kategori baik tetapi kategori kurang baik mendominasi hasil penelitian. Penelitian ini sejalan dengan penelitian yang dilakukan oleh Syukrinawati RP tahun 2014 tentang tingkat pengetahuan penggunaan antibiotik oleh mahasiswa kepaniteraan klinik Departemen Bedah Mulut RSGM-P FKG USU. $^{7}$

Pengetahuan responden sangat berpengaruh terhadap penggunaan antibiotik. Penelitian yang dilakukan oleh Irma Fatmawati tentang tinjauan pengetahuan, sikap, dan perilaku penggunaan antibiotik pada mahasiswa kesehatan dan non kesehatan di Universitas Muhammadiyah Surakarta menunjukkan adanya hubungan pengetahuan dan sikap atau perilaku penggunaan antibiotik. ${ }^{9}$

Ada beberapa hal yang mungkin dapat memengaruhi kurangnya tingkat pengetahuan responden yaitu pada masa perkuliahan responden kurang memperhatikan materi tentang penggunaan antibibiotik yang dibawakan oleh dosen sehingga responden tidak begitu memahami materi. Kemungkinan juga pada saat sekarang ini responden tidak pernah membaca atau mempelajari kembali materi-materi tentang penggunaan antibiotik yang didapat pada masa perkuliahan.

Cara yang dapat digunakan untuk meningkatkan pengetahuan penggunaan antibiotik dikalangan mahasiswa profesi yaitu dapat dilakukan pelatihan intensif dan rutin tentang penggunaan antibiotik atau mengadakan seminar tentang penggunaan antibiotik. Dalam penelitian yang dilakukan oleh Pranata $^{10}$ didapatkan bahwa ada perbedaan pengetahuan penggunaan antibiotik sesudah dan sebelum mengikuti pelatihan di Instalasi Rawat Jalan Bagian Ilmu Kesehatan Anak RSUP Dr. Kariadi. Membaca juga merupakan salah satu cara yang dapat ditempuh untuk meningkatkan pengetahuan seseorang. Penelitian yang dilakukan oleh Wijayanti ${ }^{11}$ tentang hubungan antara minat baca dengan prestasi belajar pada mata kuliah asuhan kebidanan II pada mahasiswa semester III Akbid Mitra Husada Karanganyar dan penelitian yang dilakukan oleh $\mathrm{Hardi}^{12}$ tentang pengaruh minat membaca buku terhadap hasil belajar mahasiswa BKK Akuntansi menunjukkan bahwa dengan membaca dapat meningkatkan pengetahuan seseorang. ${ }^{10-12}$

\section{SIMPULAN}

Berdasarkan hasil penelitian yang dilakukan mengenai tingkat pengetahuan mahasiswa profesi program studi pendidikan dokter gigi terhadap penggunaan antibiotik di RSGM UNSRAT Manado, maka dapat diambil kesimpulan bahwa tingkat pengetahuan mahasiswa profesi tentang penggunaan antibiotik tergolong kurang baik.

\section{SARAN}

1. Diharapkan kepada institusi pendidikan untuk memberikan himbauan kepada 
mahasiswa profesi yang akan memasuki klinik akan pentingnya pengetahuan penggunaan antibiotik.

2. Diharapkan kepada seluruh mahasiswa profesi program studi pendidikan dokter gigi untuk lebih meningkatkan lagi pengetahuan tentang penggunaan antibiotik dengan cara membaca atau mempelajari kembali materi yang telah didapat pada masa perkuliahan.

3. Diharapkan kepada seluruh mahasiswa profesi program studi pendidikan dokter gigi untuk lebih meningkatkan pengetahuan dengan cara mengupdate ilmu secara kontinyu melalui pelatihan atau seminar penggunaan antibiotik.

\section{DAFTAR PUSTAKA}

1. Setiabudy R. Farmakologi dan Terapi. Edisi ke-5. Jakarta: FK UI; 2011. p. 585-9, 718, 727.

2. Utami ER. Antibiotika, Resistensi, dan Rasionalitas Terapi. Malang: Sains dan Tekhnologi UIN; 2012. p. 125, 128-29.

3. Berita Satu. Indonesia Peringkat ke-8 Kebal Obat di Dunia. Jakarta: Berita Satu; [diakses 10 Mei 2015]. Diunduh dari http:

//sp.beritasatu.com/home/Indonesiaperingkat-ke-8-kebal-obat-didunia/5414.

4. Kementerian Kesehatan RI. Pedoman Umum Penggunaan Antibiotik. Jakarta: Kementerian Kesehatan RI; [diakses 10 Mei 2015]. Diunduh dari http:binfar.kemkes.go.id/?wpdmatc=p rocess\&did=MzYuaG90bGluaw==.

5. Tiara Selvi. Bahaya Penggunaan Antibiotik yang Tidak Rasional. Bangka Belitun Kementerian Kesehatan RI g: Radar Bangka; [diakses 10 Mei 2015].
Diunduh dari http: //www.radarbangka.co.id/rubric/detail /persepktif/6635/bahaya-penggunaanantibiotik-yang-tidak-rasional.html.

6. Pendersan GW. Buku Ajar Praktis Bedah Mulut. Edisi ke-1. Jakarta: Buku Kedokteran EGC; 2012. p. 116, 198201.

7. Syukrinawati RP. Tingkat Pengetahuan Penggunaan Antibiotik oleh Mahasiswa Kepaniteraan Klinik Departemen Bedah Mulut RSGM-P FKG USU. Medan: Universitas Sumatera Utara; 2014. p. 2, 15.

8. Kementerian kesehatan RI. Modul Penggunaan Obat Rasional. Jakarta: Kementerian RI; [diakses 18 Agustus 2015]. Diunduh dari http://binfar.kemkes.go.id/2014/12/m odul-penggunaan-obat-rasional/.

9. Fatmawati I. Tinjauan Pengetahuan, Sikap dan Perilaku Penggunaan Antibiotik Pada Mahasiswa Kesehatan dan Non Kesehatan di Universitas Muhammadiyah Surakarta. Surakarta: Universitas Muhammadiyah; 2014. p. 4-8.

10.Pranata GA. Perbedaan Kualitas Penggunaan Antibiotik Sebelum Dan Sesudah Pelatihan Penggunaan Antibiotik Secara Bijak [Skripsi]. Semarang: Universitas Diponegoro; 2014. p. 9-11.

11.Wijayanti. Hubungan Minat Baca Dengan Prestasi Belajar Pada Mata Kuliah Asuhan Kebidanan II Pada Mahasiswa Semester III Akbid Mitra Husada Karanganyar. Jurnal Kesmadaska 2011;2(1):53-9.

12.Hardi, Asriati N, Purwaningsih E. Pengaruh Minat Membaca Buku terhadap hasil Belajar Mahasiswa BKK Akuntansi. JPP. 2014;3(7):5-11. 